Philippe Blanc

Carolina Portugeis

Colaborador Fernando Soffia R

Ubicación Centro Cultural Estación Mapocho

Mandante Colegio de Arquitectos de Chile

Materialidad Madera, tela y acero

Superficie $5.800 \mathrm{~m}^{2}$

Año proyecto 2001

\title{
Montaje XIII Bienal de Arquitectura
}

El Colegio de Arquitectos llamó a concurso a los arquitectos menores de 35 años para el montaje de la XIII Bienal de Arquitectura a realizarse el 2002. El montaje para la muestra debía enmarcarse dentro de la temática de la Bienal: la Globalización (i!) y dentro de un presupuesto de $\$ 60.000 .000$.

El montaje Bienal no es un problema de forma. Se trata de recoger una cierta vida. La Bienal no es solamente ir a ver proyectos, si fuese estrictamente ver proyectos bastaría con publicar un catálogo de las obras. La Bienal no es un catálogo de obras, de hecho podríamos definirla como todo aquello que la diferencia de ver un catálogo.

Se proponen 2 tipos de recorrido: el paseo y el atajo. Así hay partes de la exposición que se ven de un golpe de vista (atajo) y otras que se van descubriendo de a poco (paseo).

El carácter de la muestra es el de un gran taller, pensamos en la posibilidad de exponer planos originales, muestras de materiales que acompañan los proyectos, croqueras, maquetas

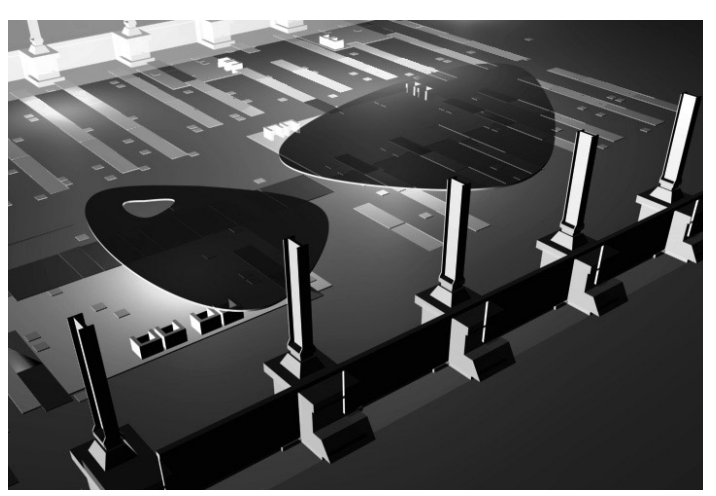

de estudio. No es una muestra en limpio, es mas bien, una suerte de gran borrador.

Se elige trabajar con mesas, sillas, esteras y una pantalla de proyecciones.

En contraste con las mesas se propone un gran plano vertical de $10 \mathrm{~m}$ de alto que recorre toda la estación en su largo. En esta pantalla se muestran tanto imágenes de gran formato de las distintas exposiciones que ocurren bajo ella, como charlas y distintos lugares de la muestra, dando una suerte de vista resumida del total, abarcándola de un golpe de vista. En la plaza de acceso la pantalla muestra imágenes del interior transformándose en un cine al aire libre.

\section{Philippe Blanc Cavieres}

Arquitecto PUC, 1999. Ha trabajado en las oficinas Baixas-Del Río y de Teodoro Fernández. Desde el 2000 combina su trabajo en forma independiente con su actividad como profesor instructor en la Escuela de ura de la PUC.

Carolina Portugeis Waissbluth

Arquitecta PUC, 2000. Ha trabajado en las oficinas de Sebastián Irarrázaval y de Rodrigo Pérez de Arce. Actualmente ejerce de manera 列 de $3^{\circ}$ semestre de la Escuela de Arquitectura de la PUC.
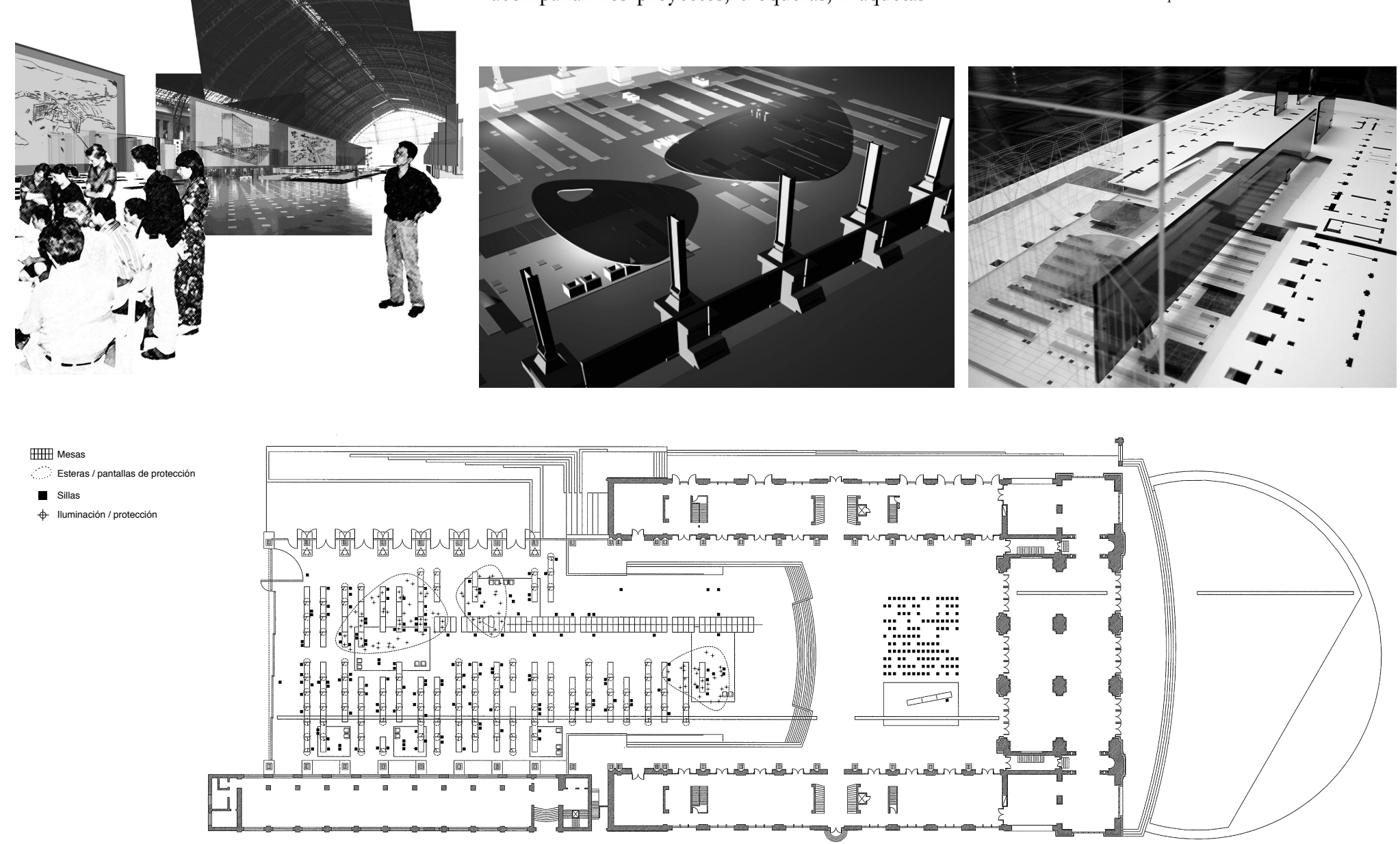